\title{
EKSTRAK METANOL DARI DAUN MAHKOTA DEWA (Phaleria macrocarpa) SEBAGAI INHIBITOR KOROSI BAJA DALAM ASAM KLORIDA
}

\author{
Azimatur Rahmi, Emriadi, dan Admin Alif \\ Laboratorium Elektrokimia/FotokimiaJurusan Kimia FMIPA, Universitas Andalas \\ e-mail: Emriadi_62@yahoo.com
}

\begin{abstract}
Extract of Phaleria macrocarpa leaves have been studied as corrosion inhibitor for mild steel of hydrochloric acid solution $2.0 \mathrm{~N}$. The efficiency of inhibition was evaluated by gasometric method and electrochemical analysis. The temperature and concentration effects on the inhibitors performance were also investigated. The result obtained showed that the extract is one of promising candidate as an inhibitors for the corrotions of mild steel in $\mathrm{HCl}$ media, inhibition efficiency increase as the extract concentration is evaluated. The activation energy (Ea) increase with the addition of the extract. Where inhibition of extract on the steel surface obey modified Langmuir isotherm equation. Potentiodynamic polarization curve indicated the Phaleria macrocarpa leaves extract play role as the anodic type inhibitor.
\end{abstract}

Keywords : Corrosion inhibition, mild steel, Phaleria macrocarpa, hydrochloric acid.

\section{PENDAHULUAN}

Dalam proses industri, biasanya digunakan larutan asam untuk membersihkan kerak dan karat yang melekat di permukaan baja. Asam yang banyak digunakan adalah asam klorida, akan tetapi proses ini dapat menyebabkan campuran dari baja tersebut terkorosi sehingga ketahanannya berkurang ${ }^{[1]}$. Penambahan inhibitor ke dalam medium korosif merupakan salah satu metode yang digunakan untuk melindungi permukaan baja dan untuk menurunkan laju korosi yang terjadi. Inhibitor dapat menghalangi ion-ion agresif dengan membentuk lapisan yang teradsorbsi pada permukaaan baja ${ }^{[2]}$.

Pada umumnya, inhibitor korosi berasal dari senyawa organik dan anorganik yang mengandung gugus yang memiliki pasangan elektron bebas, seperti: nitrit, kromat, fospat, urea, fenilalanin, imidazolin, dan senyawasenyawa $\operatorname{amin}^{[3]}$. Inhibitor tersebut sebagian besar berasal dari senyawa sintetis yang bersifat toksik dan tidak ramah lingkungan. Oleh karena itu, banyak peneliti yang mengembangkan penggunaan ekstrak tumbuhtumbuhan sebagai inhibitor terutama untuk baja dalam medium asam, seperti: daun kemangi $^{[4]}$, lidah buaya ${ }^{[5]}$, daun mint, daun kopi, mangga, jeruk, serikaya, daun tembakau, dan kentang ${ }^{[6]}$.

Untuk ikut berkontribusi dalam pengembangan inhibitor korosi dari bahan-bahan alami, maka peneliti menggunakan ekstrak dari daun mahkota dewa (Phaleria macrocarpa) dengan tujuan mengetahui keefektifan inhibisi ekstrak pada korosi baja dalam medium asam. Sebelumnya, tumbuhan mahkota dewa hanya dipakai dalam obat-obatan tradisional. Dengan penggunaannya sebagai inhibitor korosi 
diharapkan dapat meningkatkan nilai ekonomis dari tumbuhan mahkota dewa.

\section{METODOLOGI PENELITIAN}

\section{Alat dan Bahan}

Alat dan bahan yang digunakan adalah daun mahkota dewa Phaleria macrocarpa (Scheff) yang diperoleh dari daerah Lubuk Buaya Padang, metanol, $\mathrm{HCl}$, aseton, akuades, baja st 37 , neraca analitis, amplas besi, oven, potensio eDaq, carton stereo trinocular fotooptik, rotary evaporator, hotplate, dan alat-alat gelas.

\section{Pengerjaan Awal}

Batangan baja dipotong dengan diameter $\pm 2,5 \mathrm{~cm}$ dengan ketebalan $\pm 0,5 \mathrm{~cm}$. Kemudian dihaluskan dan dibersihkan dengan amplas. Potongan baja kemudian dibilas dengan akuades, dilanjutkan dengan aseton lalu dikeringkan dalam oven.

\section{Pembuatan Ekstrak Daun Mahkota Dewa Phaleria macrocarpa (Scheff)}

Sampel daun dipotong-potong kemudian dikering anginkan dan digerinda sampai halus. Sampel daun sebanyak $750 \mathrm{~g}$ dimaserasi dengan $2 \mathrm{~L}$ metanol selama 5 hari. Lalu ekstrak disaring dan dipekatkan menggunakan rotary evaporator Heidolph WB 2000.

\section{Pembuatan Medium Korosif HCl}

Dari larutan induk $\mathrm{HCl} 5 \mathrm{~N}$, dibuat medium $\mathrm{HCl} 2 \mathrm{~N}$. Lalu diencerkan dengan akuades dalam labu $50 \mathrm{~mL}$.

\section{Pembuatan Medium Korosif dengan Penambahan Ekstrak Daun Mahkota Dewa}

Ekstrak mahkota dewa ditambahkan dalam medium korosif $\mathrm{HCl}$ dengan variasi konsentrasi $1 \%, 2 \%, 3 \%, 4 \%$, dan $5 \%$. Kemudian diencerkan dengan akuades dalam labu $50 \mathrm{~mL}$.

\section{Analisis Gasometri}

Metode yang digunakan untuk mengamati laju korosi berdasarkan laju pembentukan gas hidrogen, seperti yang dilakukan oleh Obot., et al $(2011)^{[7]}$. Dari volume gas hidrogen yang dihasilkan per menit, laju korosi(CR), efisiensi $(\% \mathrm{I})$ dan derajat penutupan permukaan baja $(\theta)$ dapat ditentukan dengan rumus berikut: ${ }^{[8]}$

Efisiensi Inhibisi (EI):

$$
E I=\frac{V_{H 2 \text { blanko }}-V_{H 2 \text { inhibitor }}}{V_{H 2 \text { blanko }}} \times 100 \%
$$

Laju korosi (CR)

$$
C R=\frac{\Delta V}{\Delta t}
$$

Derajat penutupan permukaan $(\theta)$

$$
\theta=\frac{C R_{\text {blanko }}-C R_{\text {inhibitor }}}{C R_{\text {blanko }}}
$$

\section{Pengukuran Polarisasi Potensiodinamik}

Alat yang digunakan adalah potensiostat eDAQ dengan menggunakan elektroda $\mathrm{Pt}$ sebagai elektroda pembantu, elektroda $\mathrm{Ag} / \mathrm{AgCl}$ sebagai elektroda pembanding, dan baja sebagai elektroda kerja. Ketiga elektroda dicelupkan ke dalam bejana berisi medium korosif tanpa dan dengan penambahan inhibitor. Kemudian dihubungkan dengan potensiostat dan diatur potensialnya sehingga diperoleh kurva hubungan antara potensial (E) vs arus (I).

\section{Analisis dengan FTIR}

Sampel yang dianalisis dengan FTIR yaitu sampel ekstrak mahkota dewa, ekstrak daun mahkota dewa dalam $\mathrm{HCl}$, dan ekstrak daun mahkota dewa dalam $\mathrm{HCl}$ yang ditambahkan dengan serbuk besi dan didiamkan selama 5 hari. Kemudian diukur menggunakan spektrofotometer FTIR Perkin Elmer 1600 series.

\section{Analisis Foto Optik}

Sampel yang dianalisis dengan foto optik yaitu spesimen baja awal, baja yang direndam dalam $\mathrm{HCl}$ tanpa dan dengan penambahan 5\% ekstrak 
daun mahkota dewa selama 5hari. Kemudian difoto menggunakan Carton Stereo Trinoculer Foto Optic.

\section{HASIL DAN PEMBAHASAN}

\section{Analisis Gravimetric}

Laju korosi yang diamati berdasarkan laju pembentukan gas $\mathrm{H}_{2}$ dapat dilihat pada Gambar 1. Semakin tinggi konsentrasi medium korosif, maka jumlah gas $\mathrm{H}_{2}$ yang dihasilkan pada selang waktu terjadinya korosi juga akan semakin meningkat. Saat ditambahkan inhibitor yaitu ekstrak daun mahkota dewa ke dalam medium korosif maka volume gas $\mathrm{H}_{2}$ yang dihasilkan akan menurun seperti terlihat pada Gambar 2. Hal ini disebabkan adanya adsorbsi molekul dari ekstrak daun mahkota dewa pada permukaan baja akan menghambat serangan ion agresif $\mathrm{H}^{+}$yang terdapat dalam medium korosif. Semakin tinggi konsentrasi ekstrak mahkota dewa yang ditambahkan kedalam medium korosif, semakin banyak molekul ekstrak yang teradsorbsi pada permukaan baja sehingga laju korosi baja menjadi berkurang.

Efisiensi inhibisi korosi akan meningkat sebanding dengan penambahan konsentrasi ekstrak daun mahkota dewa yang tertera pada Gambar 3. Nilai efisiensi inhibisi yang tertinggi terdapat pada penambahan 5\% ekstrak daun mahkota dewa yaitu sebesar $63,56 \%$. Penurunan efisiensi ini disebabkan karena adanya senyawa heteroatom dan gugus hidroksi yang dapat teradsorbsi pada permukaan baja berupa lapisan ekstrak, sehingga menghalangi serangan ion $\mathrm{H}^{+}$dan $\mathrm{Cl}^{-}$ dari medium asam ${ }^{[1]}$.

Dari Gambar 4 dapat dilihat dengan adanya peningkatan suhu maka laju korosi juga akan semakin meningkat. Tetapi dengan meningkatnya suhu medium dapat mengakibatkan efisiensi inhibisi ekstrak daun mahkota dewa berkurang karena kecepatan oksidasi $\mathrm{Fe}$ pada permukaan baja akan meningkat seiring terjadinya kenaikan suhu. Adsorbat dari ekstrak daun mahkota dewa akan mudah terlepas dari permukaan baja ${ }^{[9]}$.

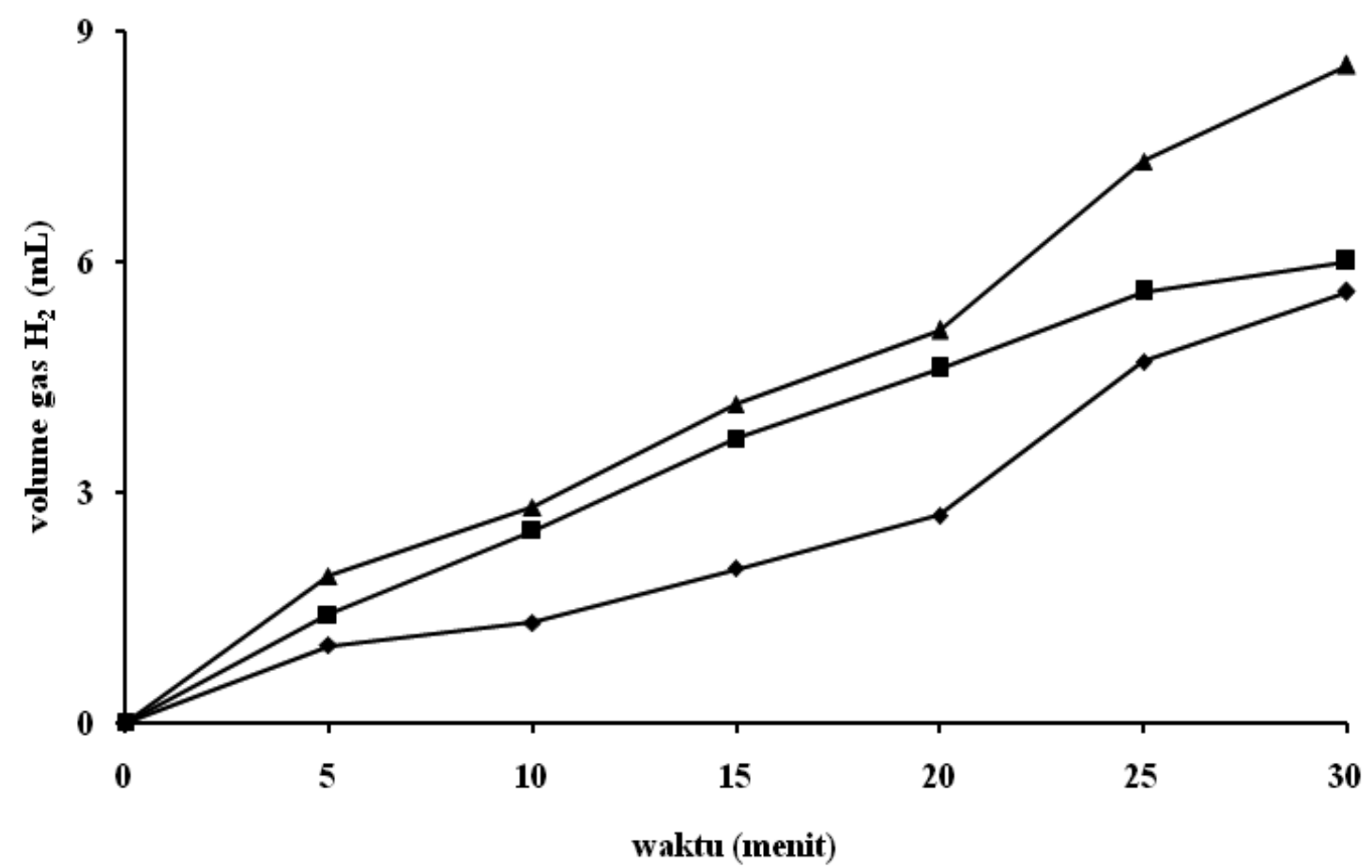

Gambar 1. Pengaruh waktu perendaman baja terhadap gas $\mathrm{H}_{2}$ yang dihasilkan dengan variasi konsentrasi $\mathrm{HCl} 2 \mathrm{~N}(\diamond), 3 \mathrm{~N}(\boldsymbol{\square}), 4 \mathrm{~N}(\boldsymbol{\Delta})$. 


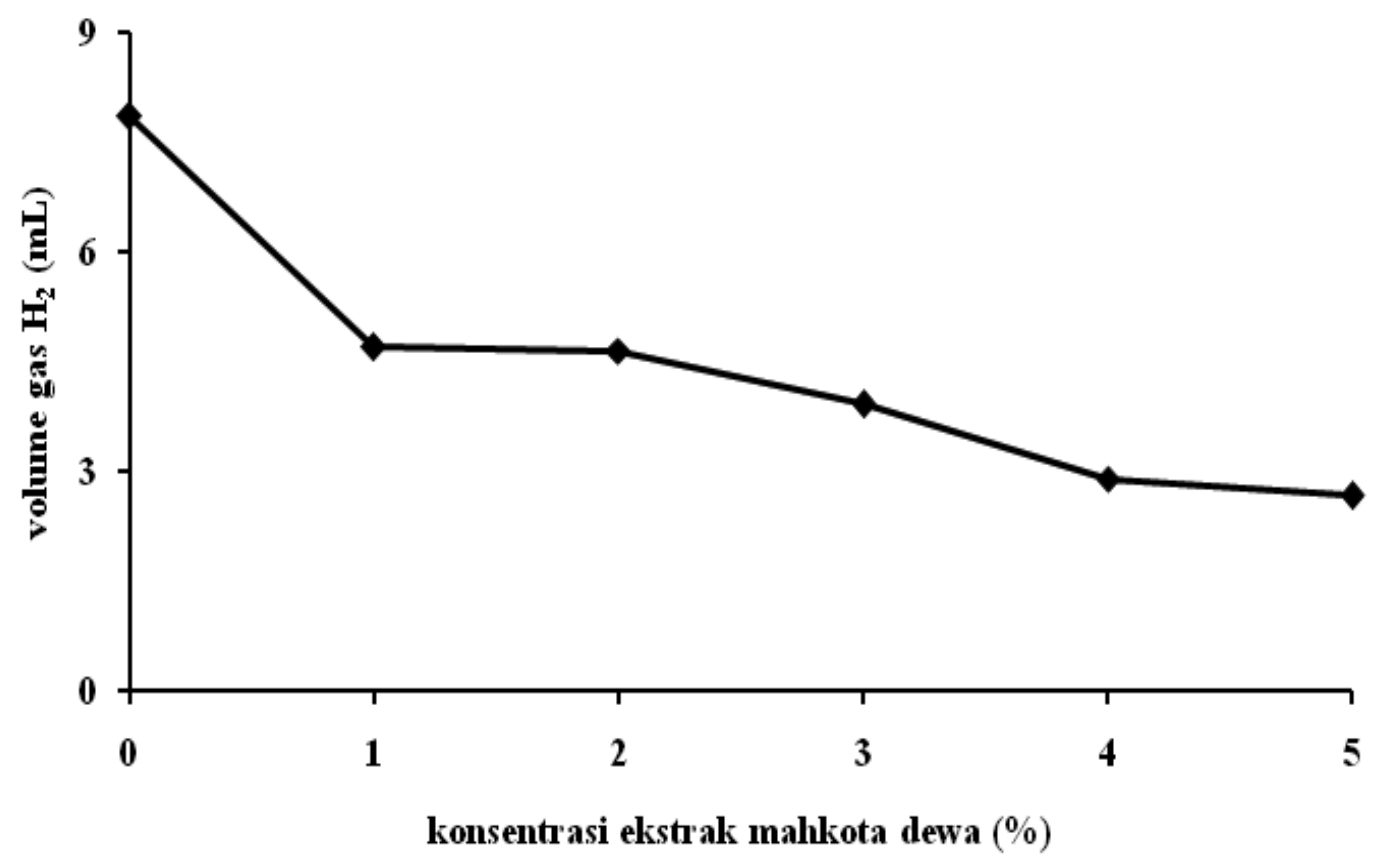

Gambar 2. Pengaruh konsentrasi ekstrak mahkota dewa terhadap volume gas $\mathrm{H}_{2}$ yang dihasilkan.

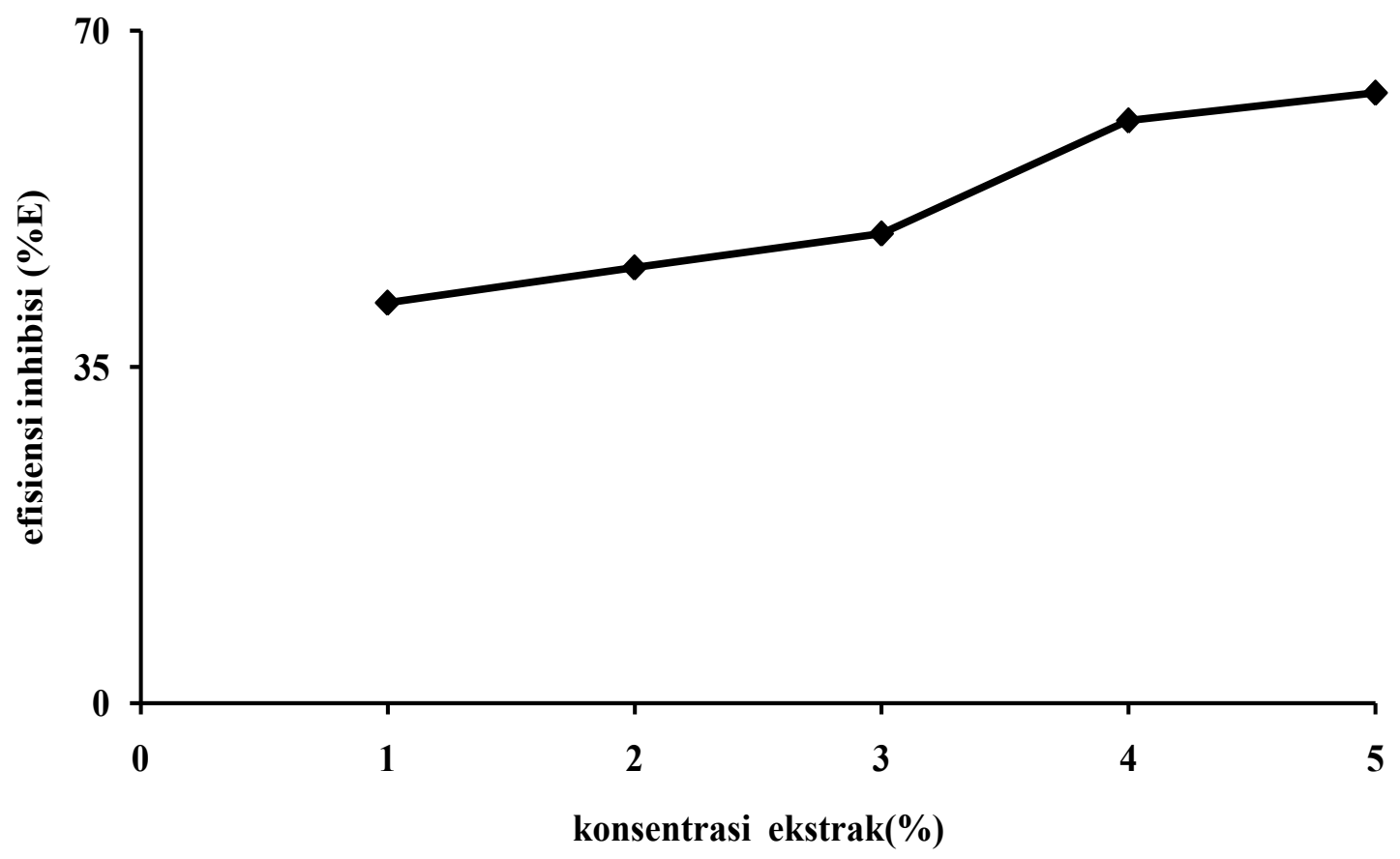

Gambar 3. Pengaruh konsentrasi ekstrak daun mahkota dewa terhadap efisiensi korosi.

Gambar 5. memperlihatkan hubungan antara $\log$ laju korosi sebagai fungsi suhu, dimana akan menghasilkan garis lurus dan nilai slope dari grafik merupakan nilai $\mathrm{Ea} / 2,303 \mathrm{R}$. Nilai
Ea akan meningkat dengan adanya penambahan ekstrak daun mahkota dewa yaitu $76.072 \mathrm{~kJ} / \mathrm{mol}$ menjadi $88.402 \mathrm{~kJ} / \mathrm{mol}$. 


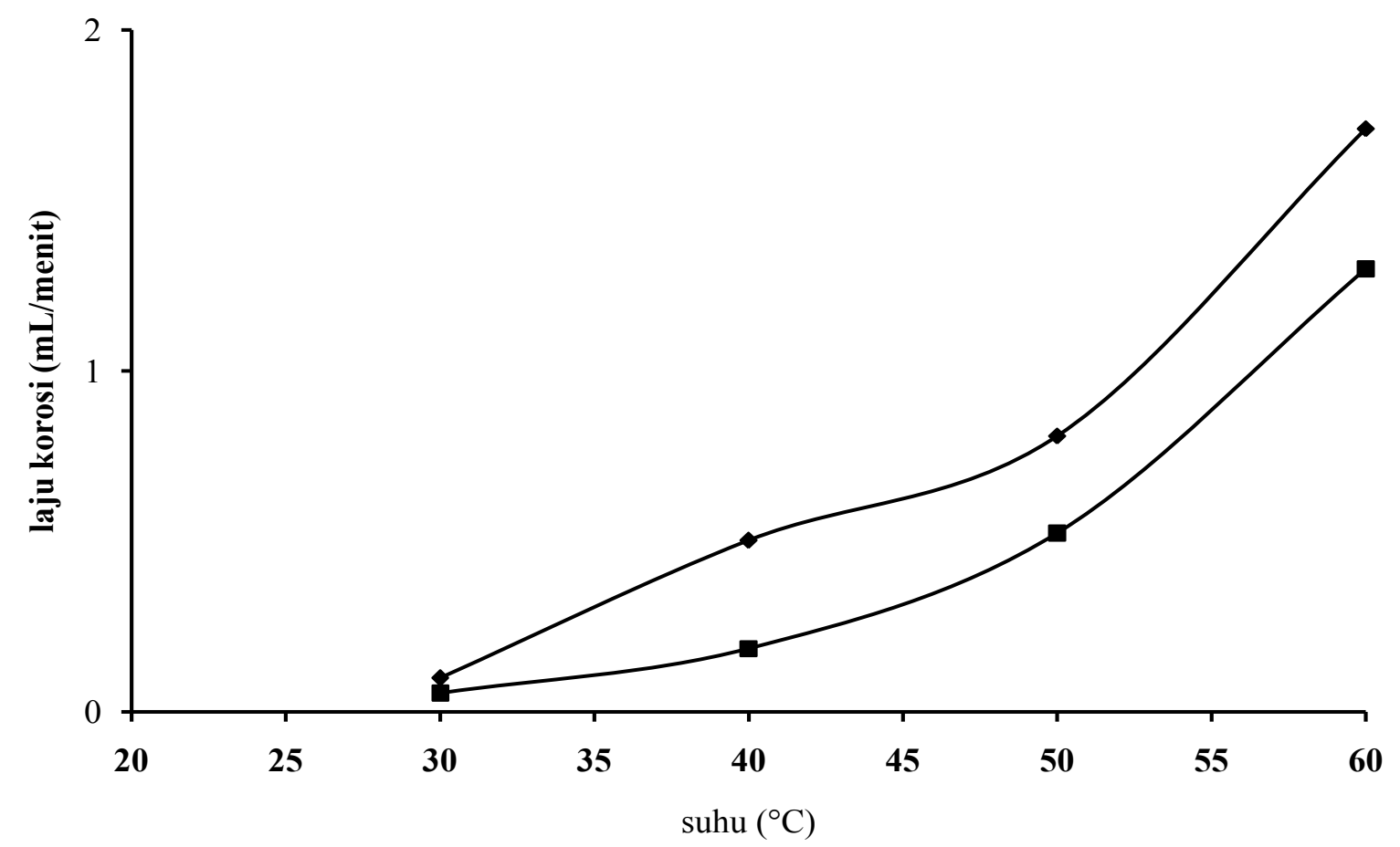

Gambar 4. Pengaruh suhu terhadap laju korosi dan efisiensi laju korosi $(\diamond=$ blanko, $\mathbf{\square}=$ ekstrak $5 \%)$.

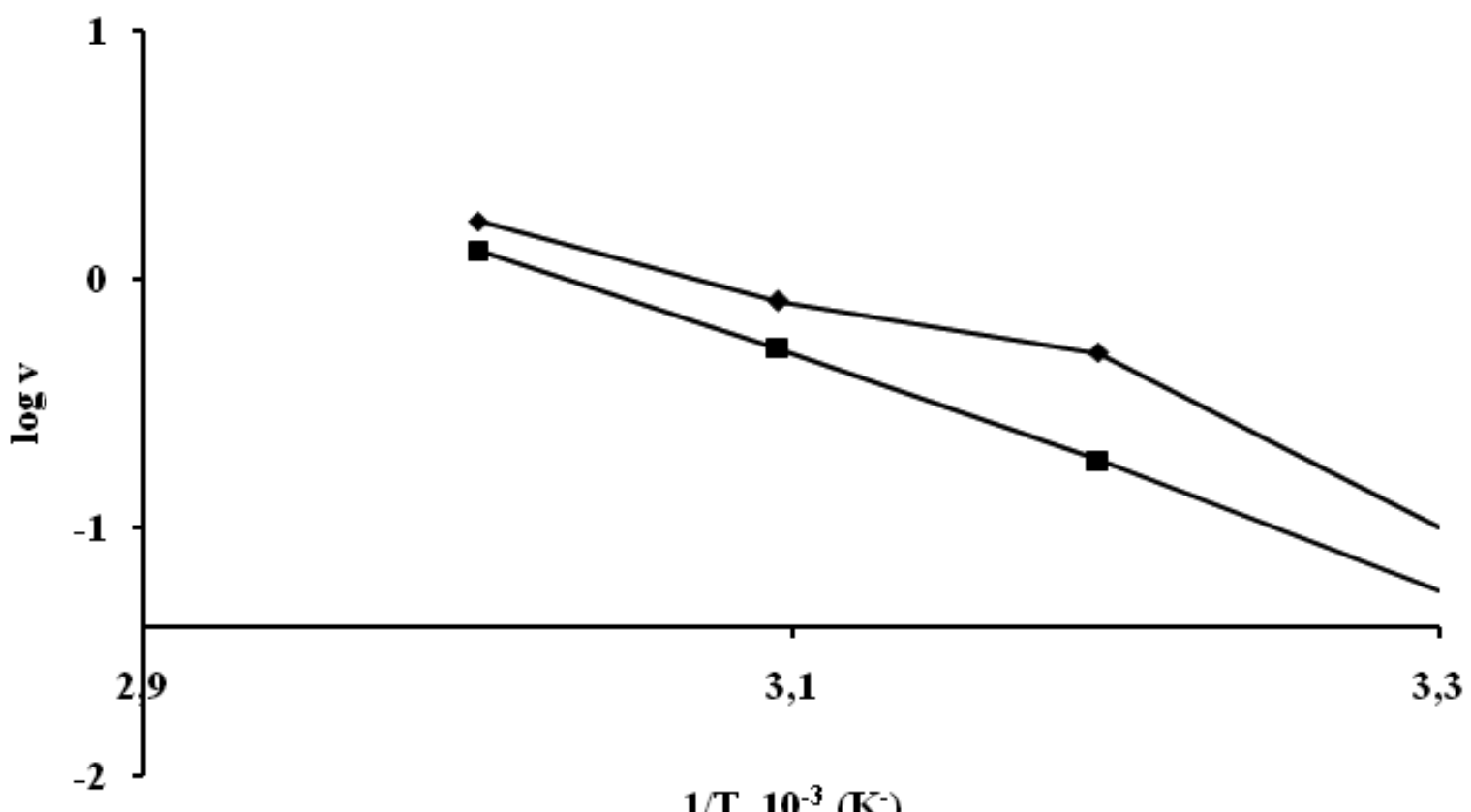

Gambar 5. Kurva Archenius $1 / \mathrm{T}$ vs $\log \mathrm{v}(\bullet=$ blanko, $\mathbf{\square}=$ ekstrak 5\%).

Semakin tinggi nilai Ea, proses korosi yang terjadi akan semakin sulit. Peningkatan ini disebabkan oleh penambahan ekstrak mahkota dewa ke dalam medium menyebabkan energi yang diperlukan dalam proses korosi akan semakin besar. Dari nilai Ea tersebut dapat diketahui pengaruh ekstrak daun mahkota dewa sebagai inhibitor korosi ${ }^{[10]}$. 
Adsorbsi isotherm diperoleh berdasarkan interaksi antara molekul adsorban yaitu ekstrak daun mahkota dewa dengan permukaan baja. Adsorbsi ini dipelajari dengan persamaan:

$$
\frac{c}{\theta}=\frac{1}{K_{a d s}}+C
$$

Proses adsorbsi dapat dijelaskan dari nilai derajat penutupan permukaan $(\theta)$ dengan adanya penambahan ekstrak daun mahkota dewa dalam medium terhadap permukaan baja. Hasil plot dari konsentrasi ekstrak/ $\theta$ terhadap konsentrasi ekstrak seperti pada Gambar 6. diperoleh garis lurus.

Untuk menentukan tipe adsorbsinya dapat diketahui dari nilai koefisien korelasi $\left(\mathrm{R}^{2}\right)$ yang didapatkan. Dimana jika nilai $\mathrm{R}^{2}$ mendekati 1 , maka terjadi adsorbsi isotherm Langmuir. Diasumsikan bahwa adsorbsi ekstrak daun mahkota dewa pada permukaan baja membentuk lapisan monolayer ${ }^{[7]}$.

\section{Pengukuran polarisasi potensiodinamik}

Kurva polarisasi potensiodinamik menunjukkan adanya interaksi antar muka dari larutan dengan elektroda yang diekstrapolasikan dengan metode Tafel untuk menentukan nilai arus korosi $\left(\mathrm{I}_{\text {korosi }}\right)$, potensial korosi $\left(\mathrm{E}_{\text {korosi }}\right)$, dan efisiensi inhibisi (\%EI). Potensial yang diberikan antara $500 \mathrm{mV}$ dan $-1000 \mathrm{mV}$. Seperti yang terlihat pada Gambar 7.

Penambahan konsentrasi ekstrak mengakibatkan potensial korosi $E_{\text {corr }}$ mengalami perubahan ke arah anodik. Hal ini mengindikasikan bahwa ekstrak daun mahkota dewa mengontrol reaksi ke arah anodik dengan membentuk senyawa kompleks pada daerah anodik dari permukaan baja ${ }^{[1]]}$.

\section{Analisis FTIR}

Analisis FTIR dilakukan untuk mengidentifikasi jenis ikatan dari gugus fungsi pada senyawa organik sehingga mendukung fakta bahwa molekul ekstrak daun mahkota dewa dapat teradsorbsi pada permukaan baja sehingga dapat memperlambat laju korosi. Gambar 8 memperlihatkan spektrum dari ekstrak daun mahkota dewa yang mempunyai gugus $\mathrm{O}-\mathrm{H}\left(3391 \mathrm{~cm}^{-1}\right), \mathrm{C}-\mathrm{H}\left(2391 \mathrm{~cm}^{-1}\right), \mathrm{C}=\mathrm{O}$ $\left(1739 \mathrm{~cm}^{-1}\right)$, C-O $\left(1075 \mathrm{~cm}^{-1}\right)$. Dari data yang didapatkan diasumsikan ekstrak daun mahkota dewa mengandung senyawa aromatis atau fenolik.

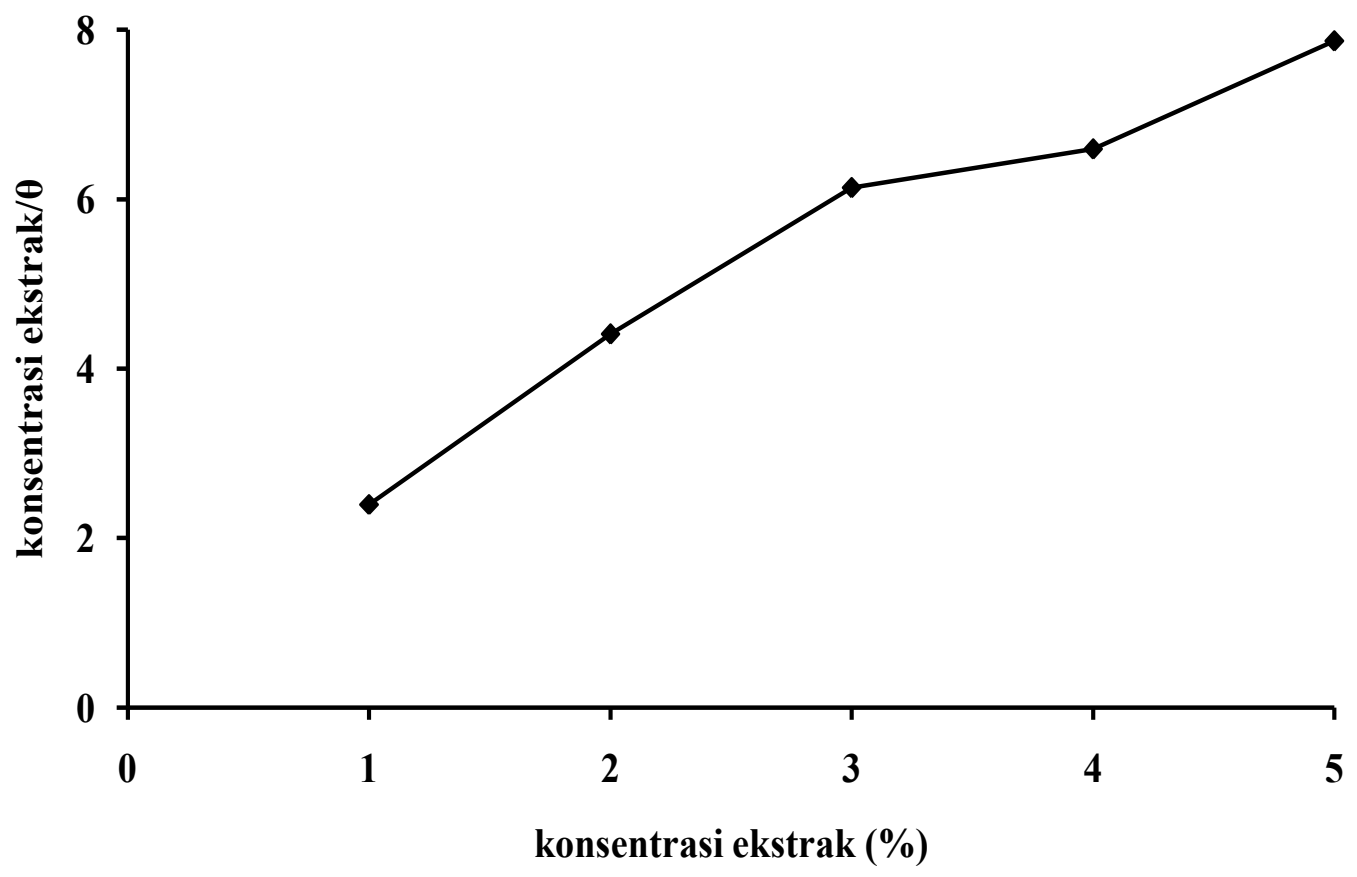

Gambar 6. Adsorbsi isotherm Langmuir ekstrak daun mahkota dewa pada permukaan baja. 


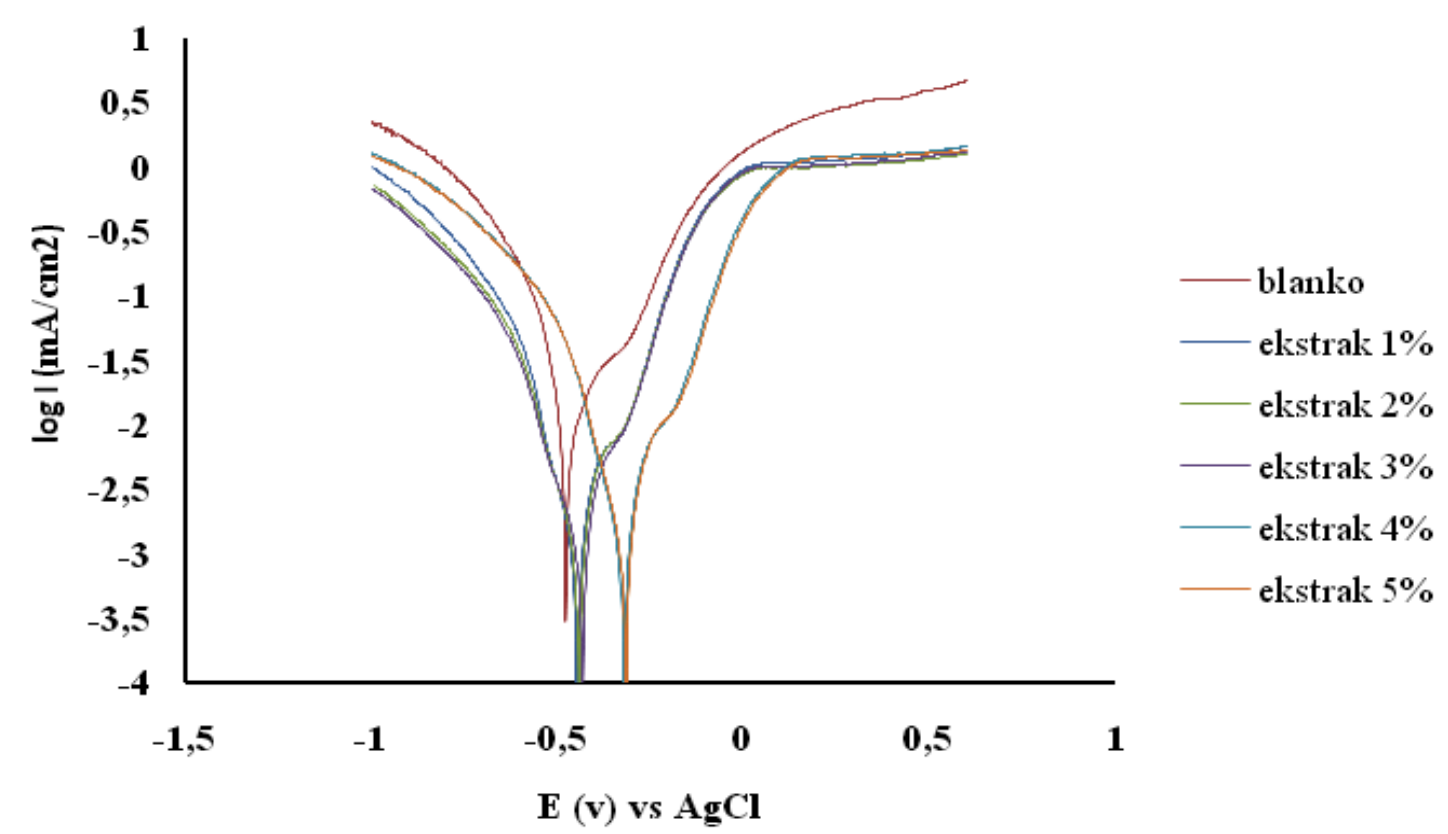

Gambar 7. Kurva polarisasi potensiodinamik tanpa dan dengan penambahan ekstrak daun mahkota dewa.

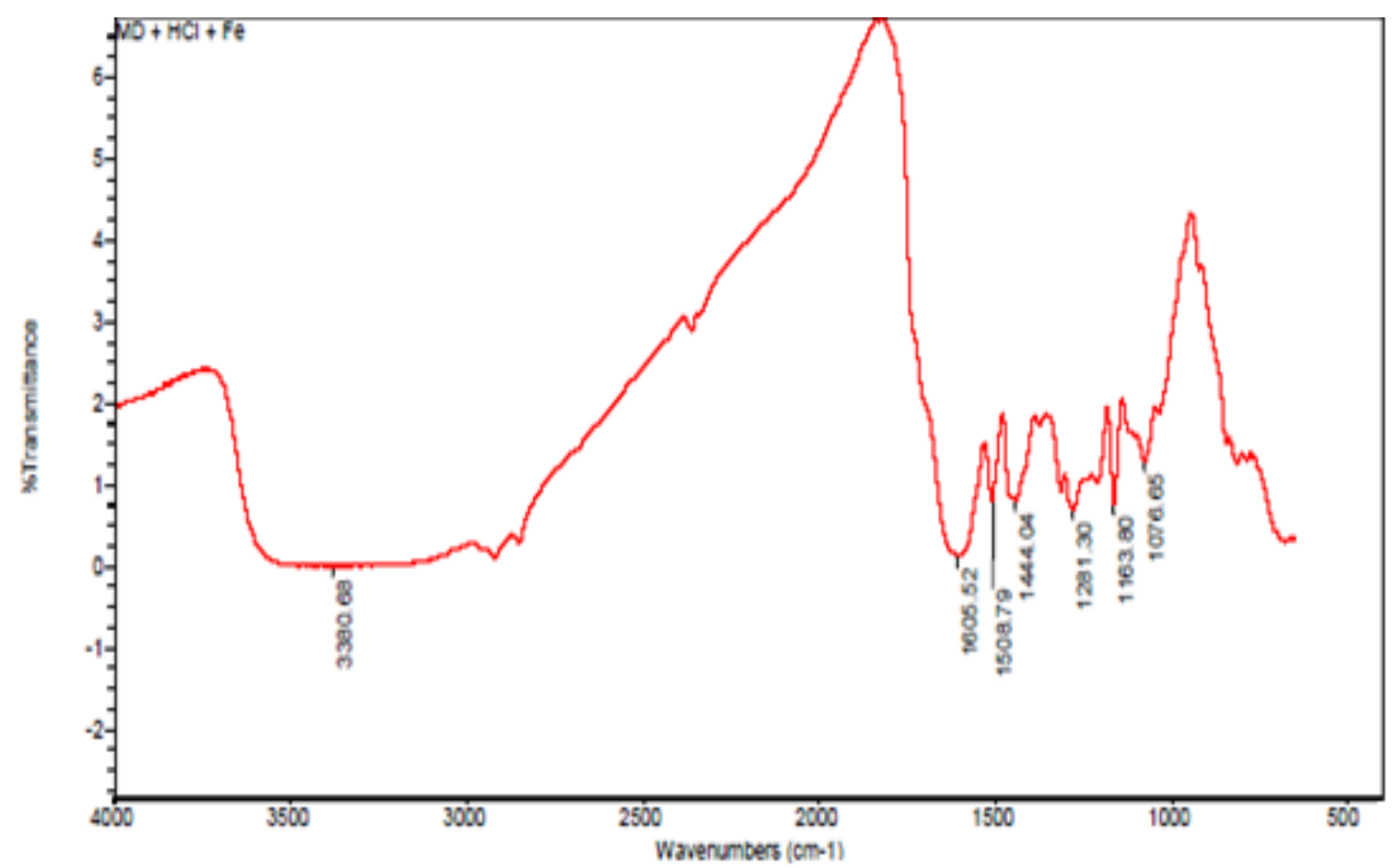

Gambar 9. Spektrum FTIR dari ekstrak daun mahkota dewa dalam medium korosif yang ditambahkan bubuk besi. 


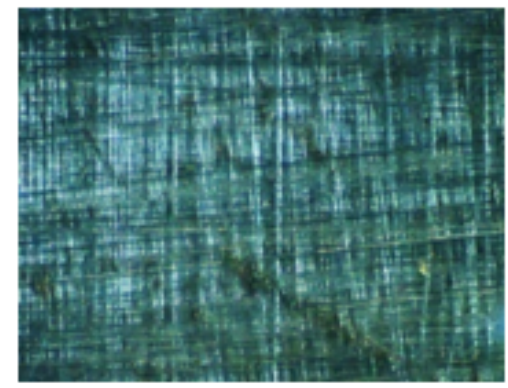

a

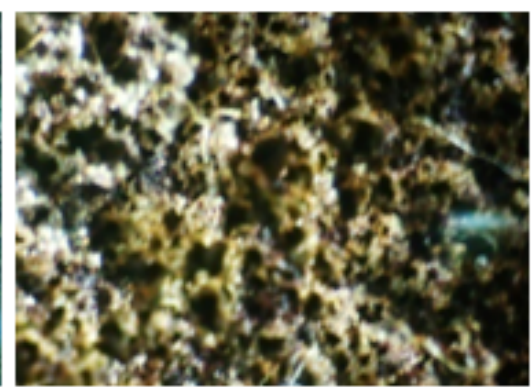

b

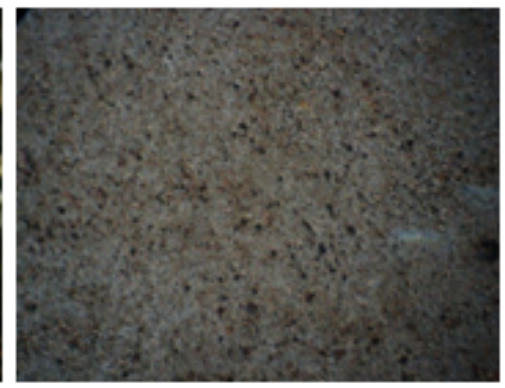

c

Gambar 10. Foto permukaan baja (a) baja awal sebelum dimasukkan dalam medium korosif. (b) baja yang direndam dalam medium $\mathrm{HCl} 2 \mathrm{~N}$. (c) Baja yang direndam dalam medium korosif dengan penambahan ekstrak 3\%, dengan perbesaran 40x.

Perbandingan spektrum FTIR ekstrak daun mahkota dewa dengan ekstrak mahkota dewa dalam medium korosif yang ditambah bubuk besi, diketahui sebagian gugus fungsi mengalami perubahan daerah serapan. Seperti gugus O-H $\left(3391-3380 \mathrm{~cm}^{-1}\right), \mathrm{C}-\mathrm{H}(1463-$ $\left.1444 \mathrm{~cm}^{-1}\right)$, dan C-O (1075 - $\left.1076 \mathrm{~cm}^{-1}\right)$, sedangkan gugus $\mathrm{C}=\mathrm{O}$ pada rentang $1700 \mathrm{~cm}^{-1}$ tidak terlihat pada Gambar 9. Perubahan tersebut disebabkan adanya ekstrak daun mahkota dewa yang teradsorbsi pada permukaan baja ${ }^{[11]}$, yang diasumsikan gugus fungsi yang terikat pada permukaan baja adalah gugus $\mathrm{C}=\mathrm{O}$, dimana senyawa-senyawa metabolit sekunder yang mengandung gugus fungsi $\mathrm{C}=\mathrm{O}$ biasanya senyawa golongan fenolik.

\section{Analisis Fotooptik}

Untuk menganalisis permukaan baja sebelum dan sesudah penambahan ekstrak mahkota dewa ke dalam medium korosif terlihat pada Gambar 10. Untuk gambar (10a) foto baja sebelum dimasukkan dalam medium korosif, terlihat permukaan baja masih bersih, tidak berlobang atau pun berpori. Ini menunjukkan belum terjadi interaksi antara permukaan baja dengan medium dan lingkungan korosif.

Pada gambar(10b) foto baja yang direndam dengan medium korosif $\mathrm{HCl} 2 \mathrm{~N}$ selama 5 hari terlihat jelas terjadinya korosi yang ditandai dengan permukaan baja menjadi kasar, berlobang, dan bewarna coklat tua. Gambar (10c) foto baja yang direndam dengan medium korosif dengan penambahan 3\% ekstrak daun mahkota dewa terlihat korosi yang terjadi tidak secepat baja yang direndam dalam medium tanpa penambahan ekstrak daun mahkota dewa. Jadi, daun mahkota dewa dapat memperlambat laju korosi.

\section{KESIMPULAN}

Ekstrak daun mahkota dewa merupakan inhibitor yang baik untuk memperlambat laju korosi baja dalam medium asam dengan efisiensi inhibisinya $63,56 \%$ untuk konsentrasi ekstrak mahkota dewa 5\%. Dari analisis potensiodinamik diketahui bahwa ekstrak daun mahkota dewa tersebut jenisnya adalah proteksi anodik dengan jenis adsorbsi Langmuir.

\section{UCAPAN TERIMA KASIH}

Terima kasih kepada Analis Laboratorium Elektrokimia dan Fotokimia Jurusan Kimia Universitas Andalas Padang atas ketersediaan alat dan bahan untuk penelitian ini.

\section{DAFTAR PUSTAKA}

1. S. Ambrish, V. K. Singh, and M. A. Quraishi, Aqueous extract of kalmegh 
(Andrographis paniculata) leaves as green inhibitor for mild steel in hydrochloric acid solution, International Journal of Corrosion., 10, 2010.

2. U. M. Eduok, U. J. Etim, A. E. Akpakpan, and S. A. Umoren, corrosion inhibition and adsorption behaviour of Cocos nucifera $L$. coir dust for mild steel in $1 \mathrm{M}$ $\mathrm{HCl}$ : synergistic effect of iodide ions, International Journal of Advanced Scientific And Technical Research., 1 338-360, (2012).

3. B. Zerga, M. Sfaira1, M. Taleb, M. E. Touhami, B. Hammouti, A. Attayibat, S. Radi, and A. T. Benjelloun, Adsorption and corrosion inhibition of some tripodal compounds for mild steel in molar hydrochloric acid medium, Der Pharma Chemica., 4(5): 1887-1896, (2012).

4. K. Nutan, A. Chaturvedi, and R. K. Upadhyay, Corrosion inhibition of mild steel by alkaloid extract of Ocimum Sanctum in $\mathrm{HCl}$ and $\mathrm{HNO}_{3}$ solution, Research Journal of Chemical Sciences., 2(5), 51-56, (2012).

5. C. Hui, Corrosion inhibition of mild steel by aloes extract in $\mathrm{HCl}$ solution medium, Int. J. Electrochem. Sci., 8 720-734, (2013).

6. M. Sangeetha, S. Rajendran, T. S. Muthumegala1, and A. Krishnaveni,
Green corrosion inhibitors-an overview, 52, (2011).

7. I. B. Obot, S. A. Umoren, and N. O ObiEgbedi, Corrotion inhibition and adsorption behaviour for aluminium by extract of Aningeria robusta in $\mathrm{HCl}$ solution : sinergistic effect of iodide ions, Journals Materials Enviroment Science., 2(1), 60-71, (2011).

8. A. O. Odiongenyi, S. A. Odoemelam, and N. O. Eddy, Corrosion inhibition and adsorption properties of ethanol extract of vernonia amygdalina for the corrosion of mild steel in $\mathrm{H}_{2} \mathrm{SO}_{4}$, Portugaliae Electrochimica Acta., 27(1), 33-45, (2009).

9. R. Saratha, S. V. Priya, and P. Thilagavathy, Investigation of citrus aurantiifolia leaves extract as corrosion inhibitor for mild steel in $1 \mathrm{M} \mathrm{HCl}, E$ Journal of Chemistry., 6, 3, 785-795, (2009).

10. A. Nahl'e, I. Abu-Abdoun, I. AbdelRahman, M. Al-Khayat, and U. A. E. Neem., Extract as a corrosion inhibitor for carbon steel in $\mathrm{HCl}$ solution, International Journal of Corrosion., 10, (2010).

11. S. Rajendran, M. Agasta, R. B. Devi, K. Rajam, and J. Jeyasundari, Corrosion inhibition by an aqueous extract of Henna leaves (Lawsonia inermis L), Zastita Materijala., 50, (2009). 